\title{
Aktualisasi Pendidikan Muhammadiyah Melalui Pengabdian Mayarakat di Asia Tenggara
}

\author{
Herwina Herwina \\ Universitas Muhammadiyah Jakarta \\ Email: wina bahar@yahoo.com \\ Ismail Suardi Wekke \\ Sekolah Tinggi Agama Islam Negeri (STAIN) Sorong \\ Email: ismail@stain-sorong.ac.id
}

\begin{abstract}
Abstrak; Tujuan penelitian ini adalah menjelaskan peranan strategis pendidikan muhammadiyah di tingkat international. Penelitian difokuskan tentang keberadaan Muhammadiyah sebagai organisasi besar tingkat dunia dalam mengaktualisasikan gerakannya melalui pengabdian Mayarakat di ASEAN. Penelitian ini adalah penelitian deskriptif analisis dengan pendekatan kuantitatif. Metode yang digunakan adalah Deskriptif analisis, kajian pustaka dan analisis isi (content analysis). Sampel penelitian dilaksanakan di 3 negara yaitu di Tangerang Selatan Banten Indonesia, di Anuban Muslim Krabi School Thailand, SMK Seri Pulai Perdana Johor Baru Malaysia. Responden dalam penelitian ini adalah para mahasiswa Fakultas IImu Pendidikan Universitas Muhammadiyah Jakarta sebanyak 41 mahasiswa. Intrumen penelitian berisi tentang respon masyarakat dalam mengenalkan Muhammadiyah sebagai gerakan dakwah sekaligus organisasi besar dan hambatan serta tantangan yang dihadapi oleh responden selama menjalani pengabdian masyarakat di tiga Negara tersebut. Hasil penelitian menunjukkan bahwa pelaksanakan pengabdian masyarakat ini, diterima dengan baik, terbukti $71 \%$ responden menyatakan pendidikan Muhammadiyah memiliki peran yang strategis dalam mengembangkan amal usahanya. Keberadaan Muhammadiyah di Indonesia, tidak terlepas dari gerakan pembaharuan dan purifikasi Islam di Timur Tengah, khususnya di Mesir, Arab Saudi, Pakistan, dan beberapa negara Islam lainnya. Gerakan social kegamaan ini memiliki tujuan mengembalikan umat Islam pada Al-Quran dan Al-Sunah. Ijtihad social di kalangan Muhammadiyah sudah menjadi suatu keharusan dan menyentuh ke seluruh kalangan, baik dari akar rumput sampai pucuk pimpinan. Dengan demikian keberadaan Muhammadiyah sebagai gerakan terus berkembang dan tidak terbatas oleh ruang dan waktu dalam melakukan aktivitas melalui persyarikatannya dan tanpa menggantungkan kekuatan dari pihak manapun dalam mengembangkan ide-ide pembaharuannya melalui perjuangan dan komitmen yang tinggi dalam mewujudkan masyarakat Islam yang sebenar-benarnya.
\end{abstract}

Kata Kunci; Pendidikan Muhammadiyah, Pengabdian Masyarakat, ASEAN

\section{Pendahuluan}

Muhammadiyah merupakan organisasi Islam terbesar di dunia, didirikan oleh KH Ahmad Dahlan pada 1912. Perjuangan Muhammadiyah terbukti dalam berkiprah dan berperan dalam membangun dan mencerdaskan bangsa. Sebagai gerakan Islam, dakwah amar makruf nahi munkar dan tajdid bersumber pada Al Qur'an dan As Sunnah. Tujuan dari gerakan ini adalah menegakkan dan menjunjung tinggi agama Islam sehingga terwujud masyarakat Islam yang sebenar-benarnya. Guna mencapai tujuan Muhammadiyah, maka digerakkanlah bebagai macam usaha. Muhammadiyah memiliki amal usaha, yang dilaksanakan dalam bentuk kelembagaan dan non kelembagaan. Salah satu amal usaha Muhammadiyah yang cukup berhasil adalah di bidang pendidikan.

Pendirian lembaga pendidikan Muhammadiyah merupakan hasil pemikiran pendidikan $\mathrm{KH}$ Ahmad Dahlan yang dapat dilihat dari beberapa komponen pendidikan yakni tujuan pendidikan, peserta didik, metode, serta kurikulum. Pendidikan membekali siswa dengan pengetahuan dan keterampilan yang diperlukan untuk mencapai kemajuan material, oleh karena itu pendidikan yang baik adalah pendidikan yang sesuai dengan tuntunan masyarakat di mana siswa hidup. Bahkan Dahlan berpendapat bahwa kemajuan materi merupakan prioritas karena dengan cara itu kesejahteraan mereka akan bisa sejajar dengan kaum kolonial. Kesemuanya menuntut pendidikan Islam harus mampu menghasilkan peserta didik yang berbudi pekerti, luhur, alim dan luas pandangan dan paham masalah ilmu-ilmu keduniaan serta bersedia berjuang untuk kemajuan masyarakat. Semua pemikiran Dahlan baik dalam 
aspek tujuan pendidikan, kurikulum, peserta didik adalah sebagai kritikan terhadap sistem pendidikan Islam tradisonal, menjalankan pendidikan yang diwarisi secara turun temurun tanpa mencoba melihat relevansi dengan perkembangan zaman. Oleh karena itu integrasi keilmuan merupakan inti dari gagasan pendidikan Islam Ahmad Dahlan. Upaya untuk mewujudkan gagasannya tersebut dengan mendirikan Muhammadiyah dan berkembanglah amal usaha sebagai berikut:

Tabel 1

Data Amal Usaha Muhammadiyah

\begin{tabular}{lll}
\hline NO & Jenis Amal Usaha & Jumlah \\
\hline 1 & TK/TPQ & 4.623 \\
2 & Sekolah Dasar (SD/MI) & 2.252 \\
3 & Sekolah Menengah Pertama (SMP/MTs) & 1.111 \\
4 & Sekolah Menengah Atas (SMA/SMK/MA) & 1.291 \\
5 & Pondok Pesantren & 67 \\
6 & Perguruan Tinggi Muhammadiyah & 171 \\
7 & Rumah Sakit, Rumah Bersalin, BKIA, BP, dll & 2.119 \\
8 & Panti Asuhan, Santunan,Asuhan Keluarga & 318 \\
9 & Panti Jompo & 54 \\
10 & Rehabilitasi Cacat & 82 \\
11 & Sekolah Luar Biaa (SLB) & 71 \\
12 & Masjid & 6.118 \\
13 & Musholla & 5.080 \\
14 & Tanah & $20.945 .504 \mathrm{M} 2$ \\
\hline
\end{tabular}

Sumber: www.muhammadiyah.or.id

Program pendidikan dilaksanakan dengan professional dan berlandaskan kepada nilai-nilai dakwah sebagai aktualisasi pendidikan di masyarakat. Dalam hal ini, Muhammadiyah memprioritaskan pengembangan kualitas dan misi pendidikan diseluruh jenjang melalui perencanaan strategis dalam merealisasikan tujuan dan cita-cita Muhammadiyah. Karakteristik pendidikan Muhammdiyah, adalah mengaktualisasikan visi dan misinya di masyarakat sebagai implementasi ideologi dan cita-cita hidup warga Muhammadiyah. Penyelenggaraan pendidikan Muhammadiyah dilaksanakan dalam perencanaan strategis untuk menghasilkan lulusan yang sesuai dengan tujuan pendidikan muhammadiyah, yaitu manusia muslim yang berakhlaq mulia, cerdas dan berguna bagi umat dan bangsa, sebagai kaderisasi gerakan Muhammadiyah. Pengembangan sekolah sekolah unggulan menjadi target program yang direalisasikan kepada seluruh masyakat dan tidak mengarah pada eksklusifisme dan semata mata mengembangkan kualitas proses pembelajaran untuk menghasilakan kader-kader umat di seluruh jenjang dalam memasuki persaingan yang keras dan kulitatif pada era globalisasi dengan kemampuan mengembangkan ciri khas pendidikan Islam yang dapat menjadi model keunggulan dimasa depan.

Globalisasi pendidikan yang terus mewarnai perkembangan masyarakat Indonesia, perlu dibatasi dengan penanaman nilai-nilai akhlakhul karimah dan penanaman nilai tauhid dan ideology Muhammadiyah. Sebagaimana hakikat tujuan Muhammadiyah adalah untuk membentuk manusia yang alim dalam ilmu agama, berpandangan luas dengan memiliki pengetahuan umum, siap berjuang mengabdi untuk Muhammadiyah dalam menyantuni nilai-nilai keutamaan pada masyarakat. Menumbuhkan semangat ilmiah dan memuaskan rasa ingin tahu, serta memungkinkan mereka mengkaji ilmu demi perkembangan ilmu pengetahuan. Menumbuhkan kesadaran manusia untuk mengabdi, dan taqwa kepada Allah, sebagai ibadah dan menguatkan ukhuwah islamiyah di kalangan kaum muslim untuk mencapai keridhaan Allah, menjauhkan murka dan siksaanNya serta melaksanakan pengabdian yang tulus ikhlas kepadaNya. 
Berdasarkan kepada kondisi saat ini, Muhammadiyah terus bergerak dalam pergolakan akhlak yang semakin mengkhawatirkan masyarakat Indonesia. Muhammadiyah sebagai organisasi yang besar memiliki struktur lengkap dari tingkat pusat sampai ke tingkat desa. Selain itu Muhammadiyah memiliki Organisasi Otonom (ORTOM) yang strukturnya juga sampai ke tingkat kelurahan/desa. Muhammadiyah dalam mengembangkan lembaga pendidikan dikelola dengan orientasi bagaimana masyarakat mempunyai peran dan ikut serta dalam memecahkan masalah pendidikan, diantaranya tedensi moral dan kemerosotan akhlak. Sebagaimana halnya kegiatan yang dilaksanakan oleh mahasiswa Fakultas IImu Pendidikan Universitas Muhammadiyah Jakarta dalam pengabdian masyarakat di beberapa wilayah, baik lingkungan sekitar, beberapa wilayah provinsi dan tingkat Internasional, seperti di Johor Baru Malaysia dan Khrabi Thailand. Pengabdian masyarakat yang dilakasanakan merupakan aktualisasi dari proses pendidikan yang telah ditempuh oleh para mahasiswa. Kegiatan ini dilaksanakan sebagai bukti bahwa mahasiswa sebagai bagian dari masyarakat perlu mengimplementasikan ilmunya di tengah masayakat dan terbiasa menghadapi tantangan pendidikan demi terwujudnya masayakat Islam yang sebenar-benarnya.

\section{Islam di Asia Tenggara}

Islam adalah agama yang besar di dunia, di segala penjuru bumi berkembang, sebagai agama rahmatan lil alamin. Ajaran Islam yang memposisikan manusia sebagai khalifah dan makhluk yang paling mulia merupakan suatu kekuatan dalam mengembangkan ajarannya dan menanamkan nilai-nilai akhlakul karimah sebagai pondasi dalam berperadaban dan bersosialisasi. Perkembangan Islam yang cukup pesat diikuti dengan perkembangan ilmu pengetahuan dan teknologi tak akan pernah pupus, melainkan semangat mensyiarkan dan menyebarkan agama terus berkembang, dan tidak memihak pada suku, ras, warna kulit kecuali hanya nilai-nilai ketaqwaan yang menjadi ukuran keimanan seseorang.

Kehadiran Islam di negara-negara yang ada di Asia Tenggara, pada mulanya didahului oleh interaksi antara masyarakat di wilayah kepulauan dengan para pedagang Arab, India, Bengal, Cina, Gujarat, Iran, Yaman dan Arabia Selatan. Pada abad ke-5 sebelum Masehi Kepulauan Melayu telah menjadi tempat persinggahan para pedagang yang berlayar ke Cina dan mereka telah menjalin hubungan dengan masyarakat sekitar Pesisir. Kondisi semacam inilah yang dimanfaatkan para pedagang Muslim yang singgah untuk menyebarkan Islam pada warga sekitar pesisir. ${ }^{1}$

Seperti awalnya, Malaysia adalah kerajaan federal di Asia Tenggara yang terletak di semenanjung Malaka dan sebagian Kalimantan Timur yang penduduknya mayoritas Islam dan Islam adalah agama resmi negara, sehingga syariat Islam ditegakkan dengan baik dan benar. Kehadiran Islam di bawa pengaruh para pedagang melalui Malaka yang menjadi pusat perdagangan saat itu. Berkembang Islam di Asia Tenggara termasuk di Indonesia, Malaysia dan Thailand, diterima terlebih dahulu oleh masyarakat lapisan bawah, kemudian berkembang dan diterima oleh masyarakat lapisan atas atau elite penguasa kerajaan. Dukungan ulama turut berperan besar terhadap penyebaran Islam di tengah komunitas yang majemuk ini, hingga akhirnya Islam dapat diterima dengan baik dan berkembang dengan pesat. Islam merupakan agama resmi Malaysia. Perkembangan Islam di Malaysia telah membawa peradaban-peradaban baru yang diakui Dunia Islam. Sampai saat ini Muslim Malaysia dikenal sebagai Muslim yang taat ibadahnya, kuat memegang hukum Islam dalam keberagaman dan suasana damai dalam menjalankan kebijakan nilai-nilai islami sehingga peran Islam semakin penting terutama ketika kebijakan tersebut dilaksanakan secara nyata.

Sejarah peradaban Islam di Asia Tenggara dijelaskan dan dicatat dalam tiga gelombang utama globalisasi yang telah mempengaruhi kawasan ini sejak kedatangan Islam sejak abad kesebelas. ${ }^{2}$ Gelombang pertama, yang diprakarsai dan didominasi oleh Islam, bertanggung jawab atas pendahuluan dan pembentukan Islam di wilayah ini hingga menjadi peradaban paling dominan. Perluasan Islam dan

${ }^{1}$ Ira. M. Lapidus, Sejarah sosial Ummat Islam. Yogyakarta: PT. Raja Grafindo Persada, 2000 , cet. II, hal 172

${ }^{2}$ Osman Bakar, Islam And The Three Waves Of Globalisation: The Southeast Asian Experience, Islam and Civilisational Renewal, Vol 1, No 4, 2013, h. 666 
peradabannya sedang berlangsung saat gelombang kedua melanda tepi Kepulauan Melayu-Indonesia dengan kedatangan kekuatan Portugis dan negara-negara Barat lainnya yang mengakibatkan penjajahan di wilayah tersebut. Gelombang ketiga, yang didominasi oleh orang Amerika, memanifestasikan dirinya pada masa pasca-kolonial yang menyaksikan Islam Asia Tenggara menempatkan dirinya kembali dalam berbagai ranah kehidupan publik. Islam Asia Tenggara sebagai produk historis pertemuan peradaban yang berabad-abad dengan budaya dan peradaban asli pra-Islam dan kemudian antara 'Islam Melayu-Indonesia' dan agama dan budaya yang baru tiba yang dibawa oleh kolonial dan pasca kolonial Barat, dengan alasan bahwa Islam di wilayah tersebut telah terkena dampak masing-masing dari tiga gelombang tersebut.

Pendidikan Islam Di Asia Tenggara mencerminkan keragaman Islam di belahan dunia dan tentu saja memainkan peran sentral dalam membentuk dan mentransmisikan tradisi keagamaan daerah. Sistem pendidikan publik di negara-negara mayoritas Muslim di Tenggara Asia termasuk pendidikan agama. Di Indonesia, pendidikan agama di sekolah negeri multi agama, setiap siswa yang termasuk salah satu lima agama yang diakui (Islam, Kristen Katolik, Kristen Protestan, Buddhisme dan Hinduisme) berhak mendapatkan ajaran agama dalam ajarannya atau agamanya (walaupun jumlah minimum siswa diperlukan sebelumnya dalam agama tertentu disediakan). Jika tidak ada instruksi agama tersedia sesuai dengan keyakinan siswa, siswa berhak untuk dimaafkan dari ajaran agama.

\section{Aktualisasi Pendidikan Muhammadiyah dalam Pemberdayaan Masyarakat}

Lahirnya Muhammadiyah di Indonesia, tidak terlepas dari gerakan pembaharuan dan purifikasi Islam di Timur Tengah, khususnya di Mesir, Arab Saudi, Pakistan, dan beberapa negara Islam lainnya. Gerakan social kegamaan ini memiliki tujuan mengembalikan umat Islam pada Al-Quran dan Al-Sunah. ${ }^{3}$ Menurut Abdul Munir Mulkhan bahwa Ahmad Dahlan sebagai pendiri muhammadiyah memiliki hubungan ideologis dengan pemikiran Ibn Taimiyah tentang gerakan pembaharuan di dunia Islam. Selain berlandasan kepada Al quran dan As sunah, kemampuan akal dan kecerdasan berpikir dapat digunakan untuk mencapai kebenaran. ${ }^{4}$ Muhammadiyah muncul dari keprihatinan dengan kemiskinan dan keterbelakangan umat Islam di Indonesia. Ahmad Dahlan mengakui bahwa sistem pendidikan barat sangat menjanjikan sebagai sebuah instrumen untuk mereformasi komunitas muslim. ${ }^{5}$

Kiprah muhammadiyah terhadap bangsa dan Negara sangat besar dibuktikan dengan banyaknya amal usaha berupa; sekolah dari tingkat anak usia dini sampai perguruan tinggi, rumah sakit, panti asuhan, koperasi, lembaga hukum dan lembaga sosial lainnya. Selain itu dibuktikan juga dengan jasa muhammadiyah terhadap ide persatuan dan kesatuan bangsa dengan dibukanya cabang-cabang muhammadiyah dari Sabang sampai Marauke. Keberhasilan KH Ahmad Dahlan mendirikan dan membawa muhammadiyah sampai tingkat internasional dengan fokus kepada pemberantasan taqlid, bid'ah dan khurafat dengan cara-cara yang arif, santun dan mengutamakana hikmah atau kebijaksanaan, secara metodologis konsep dakwah pencerahan gaya muhammadiyah meliputi tiga dimensi, ${ }^{6}$ pertama: dakwah pencerahan dalam arti membebaskan dari tahayul, bid'ah dan kurafat. Kedua: pemberdayaan masyarakat agar dapat hidup mandiri dan terwujud masyarakat yang berkemajuan sehingga tercipta masyarakat khairul ummah. Ketiga: pemberdayaan masyarakat dalam menghadapi perkembangan ilmu pengetahuan dan teknologi dalam mempersiapkan dan menghadapi perubahan muhammadiyah, melakukan dengan cara arif, elegan, dan cerdas untuk mewujudkan masyarakat Islam yang sebenar benarnya.

Keberhasilan Ahmad dahlan dalam mengintegrasikan pendidikan, yang saat itu terjadi dikotomi dua lembaga pendidikan, yakni antara sekolah dan pesantren, tidak bersatunya ilmu pengetahuan umum dan agama. Satu sisi pesantren hanya mengajarkan pendidikan agama, sementara sekolah hanya mengajarkan ilmu-ilmu umum. Melihat ketimpangan kedua lembaga tersebut Dahlan merumuskan tujuan pendidikannya yakni melahirkan pribadi yang utuh, menguasai ilmu agama dan ilmu

\footnotetext{
${ }^{3}$ Hery Sucipto, KH Ahmad Dahlan: Sang Pencerah, Pendidik dan Pendiri Muhammadiyah, Jakarta: Best Media Utama, 2010, h. 150

${ }^{4}$ Hery Sucipto, h. 59

${ }^{5}$ Muhammad Fuad, Islam, modernity and Muhammadiyah's educational programme, Vol 5, No 3, 2004, h. 402

${ }^{6}$ Din Syamsudin,dkk, Muhammadiyah dan Dakwah Pencerahan untuk Masyarakat Kelas Menengah, Jakarta: Al-Wasath, 2013, h. 5
} 
umum. ${ }^{7}$ Dengan kata lain menurut Dahlan Tujuan Pendidikan Islam adalah terbentuknya pribadi yang baik yang mengamalkan ajaran al-Qur'an dan Hadis, ${ }^{8}$ artinya lembaga pendidikan Islam mampu mengembangkan peserta didik yang mempunyai ilmu pengetahuan yang sesuai dengan al-Qur'an dan Hadis, yang bukan semata-mata dari kitab tertentu. ${ }^{9}$

Materi yang diajarkan meliputi: (a) menanamkan karakter manusia yang baik berdasarkan alQur'an dan hadis, (b) pendidikan individu, yaitu sebagai ulama untuk menimbulkan kesadaran individu yang utuh berkesinambungan antara perkembangan mental dan jasmani, akal dan hati-hati, untuk kepentingan hidup di dunia dan akhirat, (c) pendidikan kemasyarakatan untuk menumbuhkan kesediaan dan keinginan hidup bermasyarakat. ${ }^{10} \mathrm{Hal}$ ini terangkum dengan kemauan, akhlak dan semangat untuk berjuang membela agama dan masyarakat.

Pendidikan yang dikelola sangat menekankan keterlibatan masyarakat dalam proses dan program pendidikan. Untuk mewujudkan misi pendidikan seluruh komponen pendidikan seperti kurikulum, guru, metode, sarana, dan prasarana harus dirancang dengan mempertimbangkan kepentingan masyarakat (sosial). ${ }^{11}$ Proses pendidikan yang dilaksanakan dengan melibatkan masyarakat dalam merealisasikan konsep-konsep pendidikan sebagai aktualisasi mewujudkan masyarakat Islam yang sebenar-benarnya. Muhammadiyah sangat terlibat dalam pendidikan, perawatan kesehatan, panti asuhan, dan pelayanan sosial lainnya dengan Islam sebagai dasar ideologis dan moral. $^{12}$

\section{Metode Penelitian}

Penelitian ini adalah penelitian deskriptif analisis dengan pendekatan kuantitatif. Metode yang digunakan adalah Deskriptif analisis, kajian pustaka dan analisis isi (content analysis). Pengumpulan data dilakukan dengan menggunakan studi dokumentasi, kuisioneir dan wawancara. Analisis data dalam penelitian ini dilakukan secara bersamaan pada saat data dikumpulkan, kajian pustaka dan dokumentasi, dilakukan secara interaktif, dan berlangsung secara terus menerus hingga penulisan laporan.

Penelitian ini difokuskan tentang keberadaan Muhammadiyah sebagai organisasi besar tingkat dunia dalam mengaktualisasikan gerakannya melalui pengabdian Mayarakat di ASEAN. Sampel penelitian dilaksanakan di 3 negara yaitu di Tangerang Selatan Banten Indonesia, di Anuban Muslim Krabi School Thailand, SMK Seri Pulai Perdana Johor Baru Malaysia. Terlibat langsung dalam penelitian ini adalah para mahasiswa Fakultas IImu Pendidikan Universitas Muhammadiyah Jakarta sebagai responden sebanyak 41 mahasiswa. Intrumen penelitian ini berisi tentang respon masyarakat dalam mengenalkan Muhammadiyah sebagai gerakan dakwah sekaligus organisasi besar tingkat dunia dan hambatan serta tantangan yang dihadapi oleh responden selama menjalani pengabdian masyarakat di tiga Negara tersebut.

Dalam menganalisis data, digunakan analisis kuantitatif berupa data angket yang disebar kepada responden. Selanjutnya penulis menganalisis setiap butir instrument dan digambarkan dalam bentuk grafik. Sementara itu data wawancara dianalisis kualitatif, dengan tehnik analisis deskriptif, yang bertujuan untuk menggambarkan keadaan atau status fenomena, secara sistematis dan rasional (logika) dengan cara induktif.

${ }^{7}$ Ruslan Thiyib dkk, Pemikiran Pendidikan Islam; Kajian Tokoh Klasik dan Kontemporer, Yogyakarta, Pustaka Pelajar, 1999, h. 203.

${ }^{8}$ Suja'i, Muhammadiyah dan Pendidikannya, Yogyakarta, Pustaka, 1989, h.17.

${ }^{9}$ Bahtiar Effedy dan Fahri Ali, Merambah Jalan Baru Islam, Bandung, Mizan, 1986, h. 76.

${ }^{10}$ Bahtiar Effedy dan Fahri Ali, Merambah Jalan Baru Islam, h.76 .

${ }_{11}$ Abuddin Nata, Paradigma Pendidikan Islam, Jakarta, Raja Grafindo, 2001, h. 101.

${ }^{12}$ Angel Rabasa, Islamic Education in Southeast Asia, Current Trends in Islamist Ideology, Vol 2, 2005, h. 98 


\section{Implementasi Pengabdian Masyarakat di Asia Tenggara}

Pelaksanaan pengabdian masyarakat dilaksanakan oleh 41 mahasiswa Fakultas IImu Pendidikan Universitas Muhammadiyah Jakarta di Ciputat Tangerang Selatan Banten Indonesia sebanyak 10 orang, Johor Baru Malaysia sebanyak 16 dan Krabi Thailand sebanyak 15 orang.

Tabel 2

Data Instrumen

\begin{tabular}{lllll}
\hline & A & B & C & D \\
\hline 1 & 14 & 7 & 18 & 10 \\
2 & 32 & 20 & 6 & 25 \\
3 & 16 & 7 & 19 & 1 \\
4 & 1 & 12 & 20 & 8 \\
5 & 26 & 5 & 13 & 0 \\
6 & 5 & 31 & 4 & 4 \\
7 & 15 & 6 & 24 & 0 \\
8 & 14 & 5 & 32 & 7 \\
9 & 33 & 7 & 19 & 2 \\
10 & 6 & 6 & 36 & 1 \\
\hline
\end{tabular}

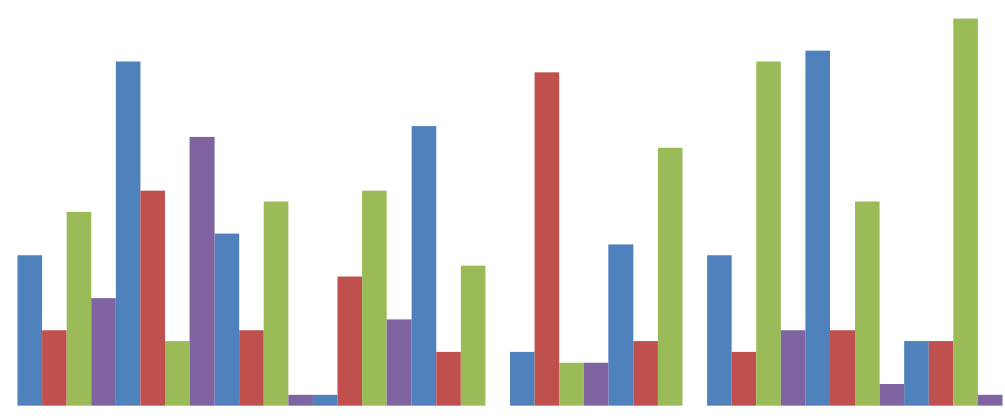

Grafik 1

Berdasarkan data di atas dapat dipahami bahwa kegiatan pengabdian masyarakat dalam mengaktualisasikan pendidikan Muhammadiyah berjalan dengan baik dan terkoordinir oleh dosen pembimbing dalam menentukan tempat pengabdian masyarakat. Kegiatan pengabdian masyarakat tingkat internasional ini terealisasi melalui proses pembelajaran di kelas sebanyak $39 \%$, mengembangkan kreativitas mahasiswa sebanyak $30 \%$, bersosialisasi dilingkungan setempat sebanyak $24 \%$ dan bakti social hanya $7 \%$. Dengan demikian kegiatan proses pembelajaran lebih mendominasi dibandingkan kegiatan yang lainnya.

Ideology Muhammadiyah disampaikan pada masyarakat tertentu, khususnya yang beragama Islam dan berhasrat mengetahui tentang Muhammadiyah dan kiprahnya sebagai organisasi besar 
tingkat dunia. Pelaksanakan dalam pengabdian masyarakat ini, diterima dengan baik oleh masyarakat setempat, terbukti $71 \%$ responden menyatakan bahwa Fakultas IImu Pendidikan Universitas Muhammadiyah Jakarta diterima dengan baik dan memiliki peran yang strategis dalam mengembangkan amal usahanya.

Hambatan yang dialami oleh responden selama kegiatan adalah selera makan yang belum terbiasa dengan lidah Indonesia. Sementara keterkaitan lokasi dan perbedaan budaya tidak terlalu menjadi hambatan bagi mereka. Solusi yang dilakukan oleh responden dalam menghadapi masalah mereka selalu sharing dan diskusi dengan teman sejawat. Keberlanjutan program ini perlu ditindaklanjuti dengan peningkatan program dan kerjasama yang lebih terkoordinir dan terprogram dengan mengembangkan ke beberapa Negara lain, seperti Vietnam, Singapura dan Philipina.

Berdasarkan hasil wawancara penulis dengan responden dijelaskan bahwa Universitas Muhammadiyah Jakarta adalah Perguruan Tinggi yang terkenal dan Fakultas IImu Pendidikan adalah Fakultas yang baik dan berkemajuan. Melahirkan sarjana-sarjana ilmu kependidikan yang kompeten dan ber-intelektual serta mewujudkan guru yang berkualitas. Hal ini terbukti dengan aktifnya kegiatan para mahasiswa dan memiliki kreativitas yang menarik. Dengan demikian program dan kerjasama perlu dilanjutkan, karena sangat strategis dalam memberdayakan masyarakat dan meningkatkan kualitas hidup melalui pengalaman dan pengabdian masyarakat tingkat international.

\section{Peran Strategis Mahasiswa dalam Pengabdian Masyarakat}

Pengabdian kepada masyarakat adalah serangkaian kegiatan dalam meningkatkan kualitas kehidupan pada masyarakat. Pengabdian masyarakat merupakan suatu gerakan proses pemberdayaan diri untuk kepentingan masyarakat. Pengabdian masyarakat bersifat kontinual dan jangka panjang, karena dalam membangun sebuah masyarakat dibutuhkan partisipasi semua pihak, termasuk mahasiswa. Banyak aspek yang harus disentuh untuk menjadikan suatu masyarakat itu baik, karakternya, budayanya, sampai pola pikirnya juga harus disentuh untuk benar-benar menciptakan sebuah masyarakat yang beradab.

Mahasiswa dalam melaksanakan perkuliahan, dituntut melaksanakan pendidikan, penelitian dan pengabdian masyarakat sebagai Tri dharma, di perguruan tinggi Muhammadiyah dikenal dengan istilah catur dharma perguruan tinggi. Pelaksanaan pengabdian masyarakat yang dilaksanakan oleh mahasiswa merupakan salah satu kewajiban yang ditempuh dengan menerapkan ilmu pengetahuan yang dimiliki ke tengah masayarakat. Pengabdian kepada masyarakat dapat dilakukan berbagai kegiatan positif. Kesempatan mahasiswa untuk bersosialisasi dengan masyarakat dan dapat berkontribusi nyata. Sebagai agen of change, mahasiswa memiliki fungsi dan peran yang jelas dalam penyambung lidah rakyat untuk mengembangkan dan mencerdaskan serta memberdayakan masyarakat dalam meningkatkan kualitas hidup mereka.

Pengabdian masyarakat dapat pula sebagai bentuk sosialisasi dan aktualisasi diri mahasiswa dengan ilmu yang sudah didapatkan di bangku perkuliahan dan diaplikasikan di tengah-tengah masyarakat demi memajukan kesejahteraan rakyat dan mencerdaskan kehidupan bangsa. Pengabdian masyarakat diperlukan agar ilmu yang didapat oleh mahasiswa tidak disimpan untuk dirinya sendiri tetapi berusaha agar masyarakat juga merasakan manfaat dari ilmu yang dimiliki mereka. Pengabdian kepada masyarakat dapat dilakukan dengan berbagai kegiatan positif. Seperti; pembelajaran di kelas, bakti sosial, implementasi teknologi pendidikan dan transfer keilmuan atau kewirausahaan yang telah dipelajari di bangku kuliah kepada masyarakat yang tentunya akan terus berkesinambungan.

Pengabdian masyarakat mahasiswa memiliki posisi strategis dan potensial untuk mengimplentasikan teori dan pemikiran yang diperoleh di bangku kuliah, sekaligus juga untuk lebih mengenalkan kehidupan ber-Islam dan ber-Muhammadiyah sekaligus mengimplementasikannya di tengah masyarakat. Program ini dapat dijadikan salah satu pintu untuk turut membina mental dan kepribadian mahasiswa sebelum mereka menyelesaikan perkuliahan sebagai dedikasi mereka kepada bangsa dan negara, sekaligus mengembangkan gerakan dakwah dan perintisan amal usaha Muhammadiyah di segala penjuru dunia.

Mahasiswa menyalurkan kreativitas yang mereka pelajari serta mengajarkan kepada masyarakat. Kreativitas yang dikembangkan ini sangat bermanfaat bagi pengembangan ilmu pengetahuan dan mengaplikasikannya di tengah masayarakat untuk memberdayakan dengan 
menghasilkan inovasi baru dalam memberikan pelayanan kepada mereka. Keberadaan mahasiswa sangat didambakan oleh masyarakat, khususnya dalam membangun dan mencerdaskan dalam bentuk sebuah karya inovasi yang mensejahterkan mereka.

Dalam program pendidikan, partisipasi mahasiswa sangat dibutuhkan, dalam membantu proses pembelajaran. Di program ini, pembelajaran di kelas dapat dibantu mahasiswa sebagai program praktik mengajar yang sudah ditetapkan oleh fakultas. Proses yang dijalani bukan saja pengajaran di kelas, namun interaksi social di masyarakat juga dikembangkan, disamping penanaman pendidikan karakter, seperti kejujuran, atitute, norma serta nilai yang membuat perubahan menjadi lebih baik.

Potensi dalam mengembangkan dan memberdayakan masyarakat, ada pada diri mahasiswa Muhammadiyah yang sudah ditempa dengan proses pembelajaran dan fasilitas yang ada dalam merealisasikan ideology Muhammadiyah dan menjadi tonggak pengabdian masyarakat. Melalui intelegensia, kreatifitas, dan jiwa kepemimpinan yang selalu diasah, mahasiswa memiliki peran penting dan strategis bukan saja di negaranya, namun mampu mengemabnagkan sayapnya sampai ke negeri jiran Malysia dan Thailand. Kegiatan ini dapat dilakukan melalui proses pembelajaran, sebagai aktualisasi bahwa pendidikan Muhammadiyah dapat berkiprah dan berperan di tingkat internasional.

Pendidikan berbasis masyarakat pada dasarnya menenkankan masyarakat berperan dan terlibat untuk memecahkan masalah pendidikan, seperti merumuskan visi, misi dan tujuan program pendidikan. Indra Djati Sidi, misalnya berpendapat bahwa pendidikan sekolah tidak lagi diartikan secara formal melainkan juga berada diberbagai tempat dan keadaan, terutama dalam keluarga dan lingkungan masyarakat sekitarnya. Sehingga semua potensi yang ada dalam kehidupan tersebut menjadi sarana dan media pembelajaran. Suasana semacam inilah yang memberikan iklim yang kondusif bagi lahirnya masyarakat belajar (learning society). ${ }^{13}$ Sementara itu Winarno mengatakan bahwa dulu pemerintah hanya meminta partisipasi masyarakat terhadap pendidikan, tetapi tidak pernah mengatakan kepada masyarakat bahwa ini pendidikan kalian. Tidak heran jika kemudian masyarakat kurang peduli terhadap bidang pendidikan. Maka untuk memperbaiki mutu pendidikan nasional, tidak bisa tidak, pengelola pendidikan harus diserahkan dan dikembalikan kepada masyarakat ${ }^{14}$, atau kepada organisasi masyarakat. Pengembalian pengelolaan pendidikan kepada masyarakat menuntut prasyaratan ekstensial, yaitu lahirnya masyarakat madani Indonesia. ${ }^{15}$ Untuk itu, reformasi pendidikan nasional harus didasarkan pada paradigma-paradigma baru yang bertujuan untuk mewujudkan suatu masyarakat madani yang demokratis. ${ }^{16}$

Lahirnya lembaga-lembaga pendidikan yang terdiri dari berbagai model ini membuktikan bahwa secara historis pemerintah dan masyarakat bekerja sama untuk menyelenggarakan kegiatan pendidikan dan Muhammadiyah (1912) sudah mempraktekkannya jauh dari kemerdekaan Indonesia. Suasana inilah yang menyebabkan umat Islam sebagai pelopor ilmu pengetahuan dan berbagai bidang lainnya. Partisipasi masyarakat dalam melaksanakan pendidikan juga dapat dijumpai pada masyarakat Indonesia, sebelum pemerintah mendirikan sekolah atau madrasah, umat Islam telah melahirkan lembaga-lembaga pendidikan Islam seperti Surau, Langgar, Pesantren, Madrasah, dan Sekolah ${ }^{17}$, seperti lembaga pendidikan yang dikelola oleh Muhammadiyah, Nahdhatul Ulama dan al-Irsyad. Pendirian lembaga-lembaga pendidikan Islam di atas, dalam berbagai bentuk dan coraknya, merupakan upaya pendidikan berbasis masyarakat secara terbuka, sampai muncul pesantren dan madrasah.

Konsep pendidikan berbasis masyarakat pada dasarnya bagaimana menggali potensi-potensi yang positif untuk diintegrasikan dalam proses pendidikan. Lahir komunitas pendidikan (Education Community) yang akan menjadi wadah bagi masyarakat untuk mengembangkan gagasan-gagasan mengenai jenis sekolah yang diinginkan oleh masyarakat dan bangsa. ${ }^{18}$ Pendidikan Islam mengakui

${ }^{13}$ Indra Djati Sidi, Menuju Masyarkat Belajar; Menggagas Paradigma Baru Pendidikan, Jakarta, Paramadina, 2001, h. 3-9.

14 Media Indoensia, "Privatisasi Sekolah Era Otonomi”, 22 Mei 2002. Baca juga Kompas 17 April 2002.

${ }^{15}$ Media Indoensia, "Privatisasi Sekolah Era Otonomi”, 22 Mei 2002 h. 14.

16 H.A.R. Tilaar, Beberapa Agenda Reformasi Pendidikan Nasional dalam Perspektif Abad 21, Magelang, Tera Indonesia, 1998, h. 19.

${ }^{17}$ Mahmud Yunus, Sejarah Pendidikan Islam di Indonesia, Jakarta, Hidakarya Agung, 1996,

${ }^{18}$ Sindu Nata, (ed), Menggagas Paradigma Baru Pendidikan Demokrasi, Otonomi, Civil Society, Globalisasi, Yogyakarta, Kanisius, 2000, h.29. 
secara tegas bahwa peranan masyarakat sangat besar pengaruhnya terhadap perkembangan intelektual dan kepribadian individu, sebab keberadaan masyarakat merupakan laboratorium dan sumber makro yang penuh bagi memperkaya pelaksanaan proses pendidikan. ${ }^{19}$ Untuk itu, pendidikan harus mampu mengakumulasi seluruh potensi dan nilai kebudayaan suatu masyarakat dalam sistem pendidikan. Berdasarkan konsep ini, baik masyarakat maupun lembaga pendidikan, akan merasa saling memiliki dan bertanggung jawab atas berhasil atau tidaknya proses pendidikan, dalam mensosialisasikan nilai-nilai kebudayaan dan kemanusiaan.

\section{Simpulan}

Kegiatan pengabdian masyarakat merupakan pemberdayaan masyarakat dalam rangka meningkatkan kualitas hidup dan membangun kepercayaan diri mahasiswa di tingkat internasional. Muhammadiyah sebagai persyarikatan dan organisasi besar tingkat dunia memiliki amal usaha yang cukup besar dan terbukti berperan serta dalam membangun dan mencerdaskan dan memberdayakan umat. Upaya ini tidak dibatasi oleh ruang dan waktu dengan tujuan memberikan pencerahan kepada umat dan penyelenggaraan pendidikan yang berkemajuan.

Pembaharuan yang dicanangkan oleh Muhammadiyah, dalam integrasi pendidikan Islam dan pendidikan umum mencerminkan bahwa Muhammadiyah merupakan gerakan yang sangat focus kepada inovasi pendidikan dan terus mengembangkan lembaga pendidikan serta amal usahanya baik tingkat nasional maupun international. Pemberdayaan masyarakat melalui mahasiswa merupakan langkah strategis dalam mengimplentasikan ide-ide kreatif sekaligus mengembangkan gerakan dakwah dan perintisan amal usaha Muhammadiyah di segala penjuru negara.

Aktualisasi pendidikan muhammadiyah melalui pengabdian mayarakat yang dilaksanakan pada tingkat international, yang mengambil sampel di Indonesia, Malaysia dan Thailand berjalan dengan baik. Kegiatan ini menunjukkan bahwa ijtihad social di kalangan Muhammadiyah sudah menjadi suatu keharusan dan menyentuh ke seluruh kalangan, baik dari akar rumput sampai pucuk pimpinan. Dengan demikian keberadaan Muhammadiyah sebagai gerakan terus melakukan aktivitas melalui persyarikatannya tanpa menggantungkan kekuatan dari pihak manapun dalam mengembangkan ide-ide dan pembaharuannya melalui perjuangan dan komitmen yang tinggi dalam mewujudkan masyarakat Islam yang sebenar-benarnya.

\section{DAFTAR PUSTAKA}

Bakar Osman, Jurnal. Islam And The Three Waves Of Globalisation: The Southeast Asian Experience, Islam and Civilisational Renewal, Vol 1, No 4, 2013.

Djati Sidi Indra, Menuju Masyarkat Belajar; Menggagas Paradigma Baru Pendidikan, Jakarta, Paramadina, 2001.

Effedy Bahtiar dan Fahri Ali, Merambah Jalan Baru Islam, Bandung , Mizan, 1986.

Fuad Muhammad, Jurnal. Islam, modernity and Muhammadiyah's educational programme, Vol 5, No 3, 2004.

Lapidus Ira. M., Sejarah sosial Ummat Islam. Yogyakarta: PT. Raja Grafindo Persada, 2000.

Media Indoensia, "Privatisasi Sekolah Era Otonomi", 22 Mei 2002. Baca juga Kompas 17 April 2002.

Nata Abuddin, Paradigma Pendidikan Islam, Jakarta, Raja Grafindo, 2001.

Nata Sindu, (ed), Menggagas Paradigma Baru Pendidikan Demokrasi, Otonomi, Civil Society, Globalisasi, Yogyakarta, Kanisius, 2000.

Rabasa Angel, Jurnal. Islamic Education in Southeast Asia, Current Trends in Islamist Ideology, Vol 2, 2005.

Nisar Samsul, Pengantar Dasar-Dasar Pemikiran Pendidikan Islam, Jakarta, Media Pratama, 2001.

Sucipto Hery, KH Ahmad Dahlan: Sang Pencerah, Pendidik dan Pendiri Muhammadiyah, Jakarta: Best Media Utama, 2010.

Suja'i, Muhammadiyah dan Pendidikannya, Yogyakarta, Pustaka, 1989.

${ }^{19}$ Samsul Nisar, Pengantar Dasar-Dasar Pemikiran Pendidikan Islam, Jakarta, Media Pratama, 2001, h. 131 
Syamsudin Din,dkk, Muhammadiyah dan Dakwah Pencerahan untuk Masyarakat Kelas Menengah, Jakarta: Al-Wasath, 2013.

Thiyib Ruslan dkk, Pemikiran Pendidikan Islam; Kajian Tokoh Klasik dan Kontemporer, Yogyakarta, Pustaka Pelajar, 1999.

Tilaar H.A.R., Beberapa Agenda Reformasi Pendidikan Nasional dalam Perspektif Abad 21, Magelang, Tera Indonesia, 1998.

Yunus Mahmud, Sejarah Pendidikan Islam di Indonesia, Jakarta, Hidakarya Agung, 1996. 